\title{
PEMBENTUKAN AKHLAQUL KARIMAH DI MADRASAH ALIYAH SUMBER AGUNG KEMILING BANDAR LAMPUNG
}

\author{
Subni \\ Program Studi Ilmu Keperawatan STIKes Aisyah Pringsewu Lampung \\ Email: subni.asghari@gmail.com
}

\begin{abstract}
ABSTRAK
Bagi guru aqidah akhlak, melaksanakan kinerjanya dengan baik dapat mempermudah proses pembentukan akhlaq, sehingga peserta didik mampu memiliki kemampuan di bidang kognitif, psikomotorik dan afektif. Pembentukan akhlak telah dilaksanakan dengan baik oleh guru aqidah akhlak, tetapi masih ada pelanggaran yang dilakukan oleh peserta didik. Penelitian ini bertujuan untuk mengetahui faktor-faktor apa saja yang menyebabkan peserta didik melakukan pelanggaran di sekolah. Data yang diperoleh dari penelitian ini yaitu dengan cara observasi, dokumentasi dan wawancara tentang kinerja guru aqidah akhlaq dan peserta didik. Penelitian lapangan ini bersifat deskriptif kualitatif yang bersumber pada data primer, yaitu data yang langsung diperoleh dari guru aqidah akhlak dan peserta didik, dan data skunder yaitu data yang diperoleh secara tidak langsung yaitu melalui media perantara atau dari pihak lain, seperti kepala sekolah dan dewan guru yang lain. Data-data yang diperoleh kemudian dianalisa secara induktif, yakni dengan cara mengidentifikasi hal yang bersifat khusus lalu ditarik menjadi kesimpulan yang bersifat umum. Hasil penelitian ini menunjukkan bahwa masih ada pelanggaran yang dilakukan oleh siswa. Pelanggaran ini di sebabkan oleh faktor internal dari peserta didik itu sendiri dan faktor eksternal yang berasal dari lingkungan keluarga, sekolah dan masyarakat.
\end{abstract}

Kata Kunci: akhlakul karimah, madrasah aliyah, siswa

\begin{abstract}
For teachers aqidah akhlak, implement good performance can simplify the process of formation of morality, so that learners are able to have the ability in the field of cognitive, psychomotor and affective. Formation of morals has been adhered to by teachers aqidah akhlak, but still there are violations committed by learners. This study aims to determine what factors are causing learners foul in school. Data obtained from this study is by observation, documentation and interview about the performance of teachers and learners. The field research is descriptive qualitative which is based on primary data, ie data obtained directly from the teacher aqidah akhlak and learners, and secondary data is data obtained indirectly, namely through media intermediaries or from other parties, such as principals and teachers' board another. The data obtained is then analyzed inductively, by way of identifying things that are special and then pulled into general conclusions. The results of this study showed that there were violations committed by students. This violation is caused by internal factors of learners themselves and the external factors are derived from the family, school and community.
\end{abstract}

Keyword: karimah akhlakul, madrasah aliyah, student 


\section{PENDAHULUAN}

Ahlak peserta didik merupakan point yang sangat penting dalam dunia pendidikan, karena dengan akhlak yang baik, maka akan melahirkan generasigenerasi baru penerus bangsa yang akan membawa kemaslahatan untuk masyarakat dan bangsa itu sendiri. Berkaitan dengan hal tersebut, maka pembentukan akhlak peserta didik disekolah menjadi tanggung jawab bersama, dimulai dari staf, karyawan, pimpinan, guru dan peserta didik itu sendiri termasuk juga masyarakat sekitarnya.

Guru Agama Islam termasuk juga didalamnya guru Aqidah Akhlaq adalah pelaksana utama dilapangan dalam rangka pembentukan akhlak dan kepribadian peserta didik, sebagaimana dijelaskan oleh Ramayulis (2004) bahwa guru Agama bukan hanya berperan dalam memberikan pengetahuan agama islam kepada siswanya, akan tetapi juga membentuk kepribadian siswa yang bernilai tinggi An Nahlawi. (2008) juga berpendapat bahwa guru Agama sangat berperan dalam mewarnai kepribadian anak, untuk itu hendaknya pendidikan agama harus diberikan secara menyeluruh baik dalam sikap, tingkah laku sehari-hari, dan lain sebagainya. Selanjutnya Ahmad Tafsir (2008) mengatakan ada 7 point peran guru agama dalam membentuk akhlaq peserta didik yaitu: 1) Memberkan contoh atau teladan; 2) Membiasakan akhlaq yang baik; 3) Memberikan motivasi; 4)Memberikan hadiah; 5) Menghukum (dalam rangka pendisiplinan); 6) Menciptakan suasana yang berpengaruh bagi pertumbuhan positif; 7) Mengadakan kerjasama yang harmonis dengan kepala sekolah, guru-guru yang lain dan orang tua siswa.

Berdasarkan uraian diatas dapat dipahami bahwa guru aqidah akhlaq tidak hanya sekedar memberikan pengetahuan agama kepada peserta didik saja, akan tetapi juga membentuk kepribadian atau akhlaqul karimah peserta didik itu sendiri supaya menjadi pribadi muslim yang utuh. Hal tersebut sejalan dengan tujuan pendidikan agama Islam sebagaimana dikemukakan oleh Jalaluddin (2001) bahwa, tujuan pendidikan Islam adalah untuk mempertinggi nilainilai akhlaq hingga mencapai tingkat akhlaq alkarimah. Tujuan ini sejalan dan sebangun dengan tujuan yang akan dicapai oleh misi kerasulan yaitu membimbing manusia agar berakhlq mulia. Akhlaq mulia yang dimaksud, diharapkan tercermin dari sikap dan tingkah laku individu dalam hubungannya dengan Allah, diri sendiri, sesama manusia dan sesama makhluk Allah SWT serta lingkungannya.

Dalam upaya pembentukan akhlaq peserta didik dilingkungan sekolah tidak terlepas dari kinerja guru aqidah akhlaq itu sendiri, sebagaimana yang dikemukakan oleh Sanjaya (2005) bahwa kinerja adalah tingkat pelaksanaan tugas yang dapat dicapai seseorang dengan menggunakan kemampuan yang ada. Sementara itu. Sardiman (2000) mendevinisikan kinerja sebagai prestasi kerja, pelaksanaan kerja, hasil kerja atau unjuk kerja.

Berkaitan dengan hal-hal yang telah diuraikan diatas, maka penulis melakukan penelitian tentang pembentukan akhlak peserta didik di Madrasah Aliyah Hidaayatul Islaamiyah Sumber Agung Kemiling Bandar Lampung yang di laksanankan oleh guru Aqidah Ahlaq. Disekolah ini nilai-nilai akhlakul karimah sangat diutamakan seperti bersalaman dengan mengucapkan salam ketika bertemu dengan guru, membaca surat-surat pendk sebelum belajar, melaksanakan shalat dhuha pada jam istirahat pertama, shalat dhuhur berjama'ah dimasjid madarasah, memperingati hari-gari besar Islam dan lain sebagainya .

Kami selalu berusaha meningkatkan sikap akhlaq peserta didik di sekolah maupun diluar sekolah karena itu sudah menjadi tanggung jawab kami sebagai pendidik. Saya, guru, staff dan pegawai mempunyai tanggung jawab yang sama dalam setiap kegiatan pendidikan demi mencapai tujuan pendidikan Nasional. Usaha - usaha yang kami lakukan adalah sebagai berikut : memberikan nasihat dan pengajaran nilai-nilai agama dan budi pekerti, memberikan bimbingan dan pembinaan moral keagamaan melalui pembiasaan (bersalaman dan mengucap salam ketika bertemu dengan guru, membaca Al Qur'an sebelum belajar, shalat dhuha ketika jam istirahat pertama, shalat Zhuhur berjama'ah di masjid sekolah, memperingati harihari besar), memberikan sanksi yang bersifat mendidik, dengan memberikan suri tauladan yang baik terhadap peserta didik." (wawancaradengan ibu Sudarmi, S.Pd , kepala Madrasah)

Kemudian pada kesempatan yang sama Ibu Saidah, S.Pd.I, guru Aqidah Akhlaq juga menambahkan selain yang sudah disampaikan oleh kepala sekolah, kami juga membiasakan kepada anak-anak untuk memberikan sodaqoh seihlasnya setiap hari senin, memberikan infaq kematian ketika ada yang tertimpa musibah, latihan dakwah, dan tugas piket sekolah.

Dari penjelasan ibu kepala sekolah dan guru aqidah akhlak dapat disimpulkan, bahwa di madrasah ini sudah dilakukan usaha-usaha dalam rangka pembentukan akhlaq peserta didik dengan baik. Namun usaha-usaha yang dilakukan belum menunjukkan hasil yang maksimal, karena masih ada peserta didik yang melakukan pelanggaranpelanggaran peraturan yang sudah ditetapkan oleh pihak madrasah. Ibu Saidah, S.Pd.I juga menjelaskan , bahwa pelanggaran-pelanggaran yang dilakukan oleh peserta didik dikarenakan perkembangan zaman yang semakin modern, lingkungan diluar sekolah yang bebas dan tidak terkontrol, minimnya perhatian orang tua terhadap anak dirumah dan kurang 
antusiasnya peserta didik ketika proses pembelajaran di kelas.

Berbagai macam pelanggaran peserta didik diatas dapat dilihat dalam catatan dokumentasi yang dimiliki oleh ibu Sa'idah bekerja sama dengan bapak Eko Purwanto, S.Pd, selaku guru Bimbingan Konseling.

Tabel 1.Data pelanggaran peserta didik di MA Hidaayatul Islaamiyah

\begin{tabular}{|c|c|c|c|c|}
\hline No & Nama & Kelas & $\begin{array}{c}\text { Jenis } \\
\text { Pelanggaran }\end{array}$ & Jmlh \\
\hline 1 & Subjek 1 & $\mathrm{X}$ & $\begin{array}{l}\text { Merokok } \\
\text { dilingkungan } \\
\text { sekolah }\end{array}$ & 2 \\
\hline 2 & Subjek 2 & $\mathrm{X}$ & $\begin{array}{l}\text { Merokok } \\
\text { dilingkungan } \\
\text { sekolah }\end{array}$ & 2 \\
\hline 3 & Subjek 3 & $\mathrm{X}$ & $\begin{array}{l}\text { Merokok } \\
\text { dilingkungan } \\
\text { sekolah }\end{array}$ & 3 \\
\hline 4 & Subjek 4 & $\mathrm{X}$ & $\begin{array}{l}\text { Merokok } \\
\text { dilingkungan } \\
\text { sekolah }\end{array}$ & 4 \\
\hline 5 & Subjek 5 & $\mathrm{X}$ & $\begin{array}{l}\text { Merokok } \\
\text { dilingkungan } \\
\text { sekolah }\end{array}$ & 2 \\
\hline 6 & Subjek 6 & $\mathrm{X}$ & Bolos sekolah & 2 \\
\hline 7 & Subjek 7 & $\mathrm{X}$ & $\begin{array}{l}\text { Tidak shalat } \\
\text { berjama'ah }\end{array}$ & 2 \\
\hline 8 & Subjek 8 & $\bar{X}$ & $\begin{array}{l}\text { Tidak shalat } \\
\text { berjama'ah }\end{array}$ & 2 \\
\hline 9 & Subjek 9 & $\mathrm{X} 1$ & Bolos sekolah & 3 \\
\hline 10 & Subjek 10 & $\mathrm{X} 1$ & $\begin{array}{l}\text { Tidak shalat } \\
\text { berjama'ah }\end{array}$ & 3 \\
\hline 11 & Subjek 11 & $\mathrm{X} 1$ & $\begin{array}{l}\text { Merokok } \\
\text { dilingkungan } \\
\text { sekolah }\end{array}$ & 3 \\
\hline 12 & Subjek 12 & $\mathrm{X} 1$ & Bolos sekolah & 2 \\
\hline 13 & Subjek 13 & $\mathrm{X} 1$ & Bolos sekolah & 2 \\
\hline 14 & Subjek 14 & $\mathrm{X} 1$ & Bolos sekolah & 2 \\
\hline 15 & Subjek 15 & $\mathrm{X} 1$ & $\begin{array}{l}\text { Merokok } \\
\text { dilingkungan } \\
\text { sekolah }\end{array}$ & 3 \\
\hline
\end{tabular}

Dalam penelitian ini yang menjadi rumusan masalah adalah : Bagaimana pembentukan akhlaq peserta didik di MA Hidaayatul Islamiyah Sumber Agung Kemiling Bandar Lampung yang telah dilakukan oleh guru Aqidah Akhlaq?

Penelitian ini bertujuan untuk mengetahui bagaimana kinerja guru aqidah akhlaq dalam membentuk akhlaq peserta didik di MA Hidaayatul Islaamiyah Sumber Agung Kemiling Bandar Lampung dan bagaimana sikap akhlaq peserta didiknya setelah mendapatkan proses pembelajaran dari guru Aqidah Akhlaq.

Dalam membentuk akhlaq peserta didik, maka dibutuhkan kinerja yang baik dari guru Aqidah Ahlaq. Lexi, J Manulang (2004) Menjelaskan bahwa kinerja guru itu berkaitan dengan tugasperencanaan, pengelolaan pembelajaran dan penilaian hasil belajar siswa. Sebagai perencana maka guru harus mampu mendesain pembelajaran yang sesuai dengan kondisi dilapangan, sebagai pengelola maka guru harus mampu menciptakan iklim pembelajaran yang kondusif sehingga peswrta didik dapat belajar dengan baik dan sebagai evaluator maka guru harus mampu melaksanakan penilain proses dan hasil belajar peserta didik dengan baik dan benar.

Lebih lanjut Agus Salim (2004) menjelaskan bahwa tugas dan peranan guru adalah menguasai dan mengembangkan materi pembelajaran, merencanakan dan mempersiapkan pelajaran seharihari, mengontrol dan mengevaluasi kegiatan belajar siswa. Oleh karenanya kinerja guru dapat dinyatakan sebagai bentuk tingkat keberhasilan seorang guru secara keseluruhan dalam periode waktu tertentu yang dapat diukur berdasarkan tiga indikator yaitu : penguasaan bahan ajar, kemampuan mengelola pembelajaran dan komitmen menjalankan tugas dan kewajibannya.

\section{METODE}

Penelitian ini merupakan penelitian yang bersifat deskriptif, karena peneliti hanya menggambarkan dan melukiskan peristiwa tertentu. Dalam hal ini peneliti ingin mengetahui sejauh mana kinerja guru aqidah akhlak dalam membentuk akhlaq peserta didik di MA. Hidaayatul Islaamiyah Sumber Agung Kemiling Bandar Lampung. Untuk mencapai tujuan penelitian ini digunakan metode kualitatif dengan pendekatan kualitatif. Ali Muhammad (2002) Mengemukakan bahwa dengan metode kualitatif peneliti diharapkan akan memperoleh deskripsi yang mendalam mengenai subyek penelitian, memandang peristiwa secara keseluruhan dan mencoba memperoleh pemahamanyang mendalam serta memahami makna dari prilaku subjek penelitian. Mengenai penelitian kualitatif sebagai prosedur penelitian yang menghasilkan data deskriptip berupa kata tulis maupun lisan dari orangorang dan pelaku yang dapat diamati.

Sumber data yang di ambil dari penelitian ini adalah data primer dan data skunder. Data primer adalah data yang langsung diambil dari sumber asli (tidak melalui perantara) dalam hal ini adalah guru aqidah akhlaq dan peserta didik. Data ini berupa opini subyek secara individual atau kelompok dan hasil pengujian. Yang dimaksud dengan opini subyek secara individual dan kelompok adalah opini atau 
pendapat dari guru aqidah akhlaq dan peseta didik berdasarkan jawaban dari hasil interviuw. Zuhairini dkk. (2004) menjelaskan bahwa ada dua metode yang digunakan untuk mengumpulkan data primer, yaitu metode survei dan metode observasi. Berdasarkan observasi, intervieuw dan dokumentasi, data menunjukkan pembentukan akhlaq peserta didik di MA. Hidaayatul Islaamiyah Sumber Agung Kemiling Bandar Lampung telah dilaksanakan dengan baik oleh guru Aqidah Akhlaq, meskipun masih terjadi pelanggaran-pelanggaran yang dilakukan oleh peserta didik. Kemudian data yang kedua adalah data skunder yaitu data yang diperoleh secara tidak langsung melalui media perantara (diperoleh dan dicatat oleh pihak lain). menjelaskan bahwa data skunder dalam penelitian adalah data yang berupa bukti, catatan atau laporan yang telah tersusun dalam arsip (data dokumen) yang dipublikasikan. Dalam hal ini datanya berpa datadata peserta didik, data guru dan profil Madrasah Aliyah Hidaayatul Islaamiyah.

\section{HASIL DAN PEMBAHASAN}

Hasil penelitian ini menunjukkan bahwa pembentukan akhlaq peserta didik di MA. Hidaayatul Islaamiyah telah dilakukan dengan baik oleh guru aqidah akhlaq. Guru aqidah akhlaq telah melaksanakan tugasnya sesuai dengan amanah Undang-Undang Guru dan Dosen No.14 tahun 2005 yaitu : mengajar, mendidik, melatih, menilai dan mengevaluasi. Dari data yang lain, seperti dari hasil intervieuw dengan kepala sekolah juga diperoleh bahwa pihak sekolah melalui peraturan-peraturan yang diterapkan sudah semaksimal mungkin untuk menjadikan peserta didik disekolah tersebut menjadi peserta didik yang berakhlaq baik. Akan tetapi pada kenyataannya masih ada peserta didik yang melakukan pelanggaran-pelanggaran di sekolah. Pelanggaran-pelanggaran yang dilakukan oleh peserta didik ini disebabkan oleh dua faktor, yakni faktor internal, dimana tingkat kesadaran peserta didik sangat rendah sekali dan faktor eksternal, yakni lingkungan keluarga, sekolah dan masyarakat.

Saat ini ilmu pengetahuan dan teknologi berkembang dengan begitu pesatnya. Perkembangan ini tentu membawa dampak positif dan negatif yang menyebar keseluruh elemen kehidupan manusia, mulai dari ekonomi, politik, sosial budaya dan tentu juga elemen pendidikan dinegeri ini. Pada tatanan pendidikan, selain berdampak positip dengan perkembangan IPTEK ini, juga tidak sedikit dampak negatifnya yakni menurunnya nilai-nilai akhlaq, moral dan etika. Sehingga dekadensi moral terus menyelimuti manusia yang juga memiliki implikasi keberbagai ranah kehidupan manusia.

Berdasarkan hal diatas sama dengan yang telah dideskripsikan Muhtarom, dkk (2016) bahwa Terjadinya perkembangan global di segala bidang kehidupan pada saat ini, selain mengindikasikan kemajuan umat disatu pihak, juga mengindikasikan kemunduran akhlak di pihak lain. Kemajuan pengembangan IPTEK oleh manusia yang tidak seimbang dengan kemajuan moral akhlak, telah memunculkan gejala baru berupa krisis akhlak terutama terjadi di kalangan remaja yang memiliki kondisi jiwa yang labil dan emosi yang belum seimbang cenderung mudah dipengaruhi.

Disamping itu juga sudah menjadi world culture terbentuknya persaingan dunia global yang tidak bisa dihindari oleh semua manusia. Karena persaingan itu tidak bisa dihindari, maka perlu diberikan bekal untuk menghadapi persaingan dunia global itu yaitu iman dan taqwa agar terbentuk sebuah keseimbangan antara ilmu pengetahuan teknologi dengan iman dan taqwa.

Menjawab persoalan-persoalan diatas, maka Yayasan Pendidikan Hidaayatul Islaamiyah turut mengambil peran sebagai bentuk tanggung jawab dan keperdulian terhadap persoalan-persoalan umat. Saah satunya dengan mendirikan lembaga pendidikan dari tingkat Paud, TK, Madrasah Ibtidaiyah, Madrasah Tsanawiyah dan Madrasah Aliyah. Dimana lembaga pendidikan ini bertujuan untuk: a) Terwujudnya layanan pendidikan yang unggul yang ditandai dengan layanan pendidikan dengan berbagai model pembelajaran dan teknologi pembelajaran yang sesuai dengan kemampuan, bakat dan minat siswa; b). Terselenggara layanan bagi siswa berbakat akademis melalui bimbingan intensif/kegiatan ekstra kurikuler serta dimulai rintisan kelas standar nasional; c). Terciptanya lingkingan belajar yang nyaman, aman,bersig, tertib dan indah; d). Meningkatkan jumlah kualifikasi tenaga kependidikan sesuai tuntunan program pembelajaran yang berkualitas; e). meningkatkan jumlah lulusan, nilai UN secara signifikan sesuai dengan standar nasional; f). warga sekolah berprilaku sesuai dengan ajaran agama yang di anut dan berakhlaq mulia; g).berbudaya, disiplin, taat peraturan/hukum, rajin, gotong royong, menolong dan lain-lain

Selain itu Yayasan Pendidikan yang menaungi MA.Hidaayatul Islaamiyah ini juga mempunyai visi dan misi : menjadi lembaga pendidikan Islam berkualitas dan berakhlaqul karimah sebagai kontributor terdepan dalam mencetak kader da'i dalam rangka amar ma'ruf nahi munkar. Berkaitan dengan tujuan dan visi misi dari lembaga pendidikan Hidayatu Islamiyah tersebut, maka ujung tombaknya adalah bagaimana membentuk akhlaq peserta didik menjadi baik. Karena kalau peserta didik sikap akhlaqnya sudah baik merupakan langkah awal tercapainya tujuan pendidikan secara nasional. Salah satu yang mempunyai peranan sangat penting untuk mencapai tujuan tersebut adalah guru, wabil khusus guru agama ( guru aqidah akhlak untuk di madrasah) 
. Tanpa adanya kinerja yang baik dari guru, maka akan sulit terbentuk sifat akhlaq yang baik pada peserta didik. Sebagaimana di jelaskan oleh bahwa guru agama bukan hanya saja berperan dalam memberikan ilmu pengetahuan agama islam kepada siswanya, akan tetapi membentuk kepribadian siswa yang bernilai tinggi. mengemukakan bahwa guru sebagai tenaga kependidikan merupakan faktor penting penentu keberhasilan tujuan pendidikan, karena guru yang langsung bersinggungan dengan peserta didik untuk memberikan bimbingan yang akan menghasilkan tamatan yang diharapkan.

Guru adalah pendidik profesional dengan tugas utama adalah: mendidik, mengajar, membimbing ,mengarahkan, melatih, menilai dan mengevaluasi . Kalau semua tugas ini dilaksanakan dengan baik dan benar oleh semua guru, maka tujuan pendidikan maka akan terwujud dengan baik.Dalam hal pembentukan akhlaq peserta didik di Madarasah Aliyah Hidaayatul Islamiyah Sumber Agung Kemiling Bandar Lampung guru aqidah akhlaq telah melakukan tugas dan kewajibannya dengan baik sesuai dengan amanah Undang-Undang Guru dan Dosen.

Terkait dengan tugas mendidik, mejelaskan bahwa guru memberikan pendidikan sebagai orang yang mempunyai tanggung jawab terhadap pembentukan pribadi anak yang sesuai dengan ajara agama Islam, ia juga bertanggung jawab kepada Allah swt. Di MA.Hidaayatul Islaamiyah guru aqidah Akhlaq telah melaksanakan tugas mendidik dengan cara : menegur siswa tidak mendengarkan gurunya yang sedang menerangkan pelajaran di sekolah tetapi membaca komik atau novel, merokok di lingkungan sekolah, bolos sekolah, tidak shalat berjama'ah di masjid waktu shalat dhuhur ( wawancara dengan siti fatimah kelas X1).

Kemudian berkenaan dengan tugas mengajar, guru aqidaq akhlaq telah mengajarkan point-point dalam rangka pembentukan akhlaq peserta didik diantaranya : a). Memberikan nilai-nilai pengajaran keberagamaan dan akhlaqul karimah yakni melalui nasihat kebaikan di kelas, kegiatan ekstrakurikuler ke agamaan ( wawancara dengan Muhammad Akbar siswa kelas X), b). Memberikan pengajaran untuk melaksanakan pembinaan karakter dan akhlaq melalui implementasi nilai-nilai akhlaq melaui : bersalaman ketika bertemu dengan guru dan mengucapkan salam, membaca Al qur'an dan berdo'a sebelum belajar, membiasakan berpakaian yang sopan, mengadakan pesantren kilat (wawancara dengan ibu Sa'idah, S.Pd.I , guru aqidah akhlaq).

Pada proses penilaian, guru aqidah akhlaq menyampaikan konsep tentang pahala dan sanksi kepada peserta didik. Bagi peserta didik yang mempunyai prestasi, maka diberikan pujian, hadiah atau mengangkat sebagai ketua kelas. Sedangkan dalam pemberian sanksi kepada peserta didik yang melakukan pelanggaran diberikan sanksi yang positif, yaitu dengan memberikan teguran dan nasehat. Bagi yang tidak mengindahkan teguran tersebut maka akan di berikan sanksi yang bersifat mendidik berupa hafalan surat pendek. Ismail siswa kelas X mengatakan : " saya sering melihat temanteman saya yang diberi sanksi menhafal surat-surat pendek di mushola, karena mereka melakukan pelanggaran-pelanggaran tata tertib di sekolah."

Selanjutnya dalam tahap evaluasi, guru dituntut untuk memiliki kemampuan dalam menentukan pendekatan dan cara-cara evaluasi, penyusunan alat evaluasi, pengolahan dan penggunaan hasil evaluasi. Sehingga dengan kemampuan tersebut, hasil belajar peserta didik akan diketahui tingkat keberhasilannya. Ibu Sa'idah selaku guru aqidah akhlaq mengatakan bahwa ia dalam melaksanakan evaluasi pembelajarannya meliputi kegiatan pendahuluan, kegiatan inti, dan kegiatan penutup.

Pada kegiatan pendahuluan yang dilakukan adalah : menyiapkan peserta didik secara psikis dan pisik, mengajukan pertanyaan-pertanyaan yang mengaitkan pengetahuan sebelumnya dengan materi yang akan diamalkan setelah proses pembelajaran, menjelaskan tujuan dan contoh-contoh akhlaq mulia dan menyampaikan materi dan penjelasan uraian kegiata sesuai silabus.

Kemudian tahap selanjutnya yakni pada kegiatan inti, ibu Sa'idah menggunakan metode yang disesuaikan dengan nilai-nilai karakteristik peserta didik dan mata pelajaran yang dapat meliputi proses eksplorasi, elaborasi dan konfirmasi. Proses eksplorasi yaitu guru melibatkan peserta didik mencari informasi yang luas tentang topik/tema materi akhlaq dengan menerapkan prinsip keteladanan dan menggunakan beragam pendekatan pembelajaran, media pembelajaran dan sumber belajar lain.

Selanjutnya proses elaborasi yang dilakukan oleh guru antara lain membiasakan peserta didik beramal sholeh yang beragam melalui tugas-tugas tertentu yang bermakna, memfasilitasi peserta didik melalui pemberian tugas peribadatan seperti menulis khutbah jum'at, memberi kesemptan untuk berpikir, menganalisis, menyelesaikan masalah dan bertindak tanpa rasa takut, memfasilitasi peserta didik berkompertisi secara sehat untuk mennigkatkan ketuntasan pembelajaran beragama dalam hal ini siswa dianjurkan untuk berlomba-lomba dalam kebaikan, memfasilitasi peserta didik melakukan perayaan hari besar agama Islam di sekolah dengan menerjunkan langsung menjadi panitia kegiata acara tersebut, memfasilitasi peserta didik melakukan kegiatan yang menumbuhkan rasa percaya diri peserta didik. 
Dan kegiatan evaluasi yang terakhir yakni kegiatan konfirmasi. Dalam hal ini yang dilakukan oleh guru adalah memberikan pahala dan umpan balik positif dan penguatan dalam bentuk lisan, tulisan, isyarat maupun hadiah terhadap keteladanan peserta didik, memberikan konfirmasi terhadap hasil eksplorasi dan elaborasi peserta didik melalui berbagai sumber, memfaslitasi peserta didik untuk memperoleh pengalaman yang bermakna dalam mencapai kompetensi dasar seperti menjadi panitia kegiatan perayaan hari besar.

Berdasarkan hasil penelitian diatas menunjukkan bahwa pembentukan akhlaq peserta didik di Madrasah Aliyah Hidaayatul Islaamiyah Sumber Agung Kemiling Bandar Lampung telah dilaksanakan dengan baik oleh guru aqidah akhlaq. Namun demikian, pelanggaran-pelanggaran masih dilakukan oleh peserta didik. Semua pelanggaran pelanggaran itu dapat dilihat dari data-data yang penulis terima Ibu Sa'idah, S.Pd.I guru aqidah akhlaq sebagaimana berikut ini:

\section{Tabel 2.Data pelanggaran peserta didik di Madrasah Aliyah Hidaayatul Islaamiyah}

\begin{tabular}{|c|c|c|c|c|}
\hline No & Nama & Kelas & $\begin{array}{c}\text { Jenis } \\
\text { Pelanggaran }\end{array}$ & Jml \\
\hline 1. & Subjek 1 & $X$ & $\begin{array}{l}\text { Merokok } \\
\text { dilingkungan } \\
\text { sekolah }\end{array}$ & 2 \\
\hline 2. & Subjek 2 & $\mathrm{X}$ & $\begin{array}{l}\text { Merokok } \\
\text { dilingkungan } \\
\text { sekolah }\end{array}$ & 2 \\
\hline 3. & Subjek 3 & $\mathrm{X}$ & $\begin{array}{l}\text { Merokok } \\
\text { dilingkungan } \\
\text { sekolah }\end{array}$ & 3 \\
\hline 4. & Subjek 4 & $\bar{X}$ & $\begin{array}{l}\text { Merokok } \\
\text { dilingkungan } \\
\text { sekolah }\end{array}$ & 4 \\
\hline 5. & Subjek 5 & $\mathrm{X}$ & $\begin{array}{l}\text { Merokok } \\
\text { dilingkungan } \\
\text { sekolah }\end{array}$ & 2 \\
\hline 6. & Subjek 6 & $\mathrm{X}$ & Bolos sekolah & 2 \\
\hline 7. & Subjek 7 & $\mathrm{X}$ & $\begin{array}{l}\text { Tidak shalat } \\
\text { berjama'ah }\end{array}$ & 2 \\
\hline 8. & Subjek 8 & $\mathrm{X}$ & $\begin{array}{l}\text { Tidak shalat } \\
\text { berjama'ah }\end{array}$ & 2 \\
\hline 9. & Subjek 9 & $\mathrm{X} 1$ & Bolos sekolah & 3 \\
\hline 10. & Subjek 10 & $\mathrm{X} 1$ & $\begin{array}{l}\text { Tidak shalat } \\
\text { berjama'ah }\end{array}$ & 3 \\
\hline 11. & Subjek 11 & $\mathrm{X} 1$ & $\begin{array}{l}\text { Merokok } \\
\text { dilingkungan } \\
\text { sekolah }\end{array}$ & 3 \\
\hline 12. & Subjek 12 & $\mathrm{X} 1$ & Bolos sekolah & 2 \\
\hline 13. & Subjek 13 & $\mathrm{X} 1$ & Bolos sekolah & 2 \\
\hline 14. & Subjek 14 & $\mathrm{X} 1$ & Bolos sekolah & 2 \\
\hline 15. & Subjek 15 & XI & $\begin{array}{l}\text { Merokok } \\
\text { dilingkungan } \\
\text { sekolah }\end{array}$ & 3 \\
\hline
\end{tabular}

Berdasarkan tabel 2 diatas, peserta didik masih melakukan pelanggaran-pelanggaran di sekolah meskipun guru aqidah akhlaq bersama pihak sekolah telah memberikan nasihat, bimbingan, arahan dan teladan yang baik terhadap peserta didiknya. Dan dari hasil intervieuw dengan peserta didik ( Siti Muthmainnah kelas X1 ) mengatakan bahwa guru aqidah akhlaq dan pihak sekolah juga memberikan hadiah kepada pesrta didik yang prestasinya baik pada setiap akhir semester ketika pembagian raport.

Adapun faktor-faktor yang menyebabkan terjadinya pelanggaran peserta didik adalah faktor intern yaitu rendahnya tingkat peserta didik itu sendiri dan faktor ekstern yakni pengaruh lingkunga tempat paserta didik itu tinggal.Rendahnya tingkat kesadaran peserta didik disebabkan karena kurang terinternalisasinya nilai-nilai agama pada diri peserta didik dan kurangnya peserta didik dalam mengaplikasikan setiap pembelajaran yang diajarkan dalam kehidupan sehari-hari, hal ini karena kurangnya perhatian dari kedua orang tua. Kemudian berdasarkan interview dengan peserta didik yang melakukan pelanggaran di sekolah menyatakan bahwa kedua orang tua mereka jarang sekali mengingatkan mereka , karena faktor kesibukan. Selain itu, pelanggaran-pelanggaran peserta didik juga disebabkan oleh faktor bermain anak di luar sekolah yang rumahnya tidak jauh dari rumah siswa tersebut menyatakan bahwa siswa A sudah biasa nonkrong bersama teman-temannya sambil merokok. Penjelasan-penjelasan diatas juga diperkuat berdasarkan tabel wawancara dibawah ini:

\begin{tabular}{|c|c|c|c|c|c|c|c|c|}
\hline \multirow{3}{*}{$\mathrm{N}_{0}$} & \multirow{3}{*}{ Perilial } & \multicolumn{6}{|c|}{ Hasil Jawaban } & \multirow[t]{3}{*}{$\mathrm{Jm}$} \\
\hline & & \multicolumn{2}{|c|}{$\mathrm{Ya}$} & \multicolumn{2}{|c|}{$\begin{array}{l}\text { Kadang- } \\
\text { Kadang }\end{array}$} & \multicolumn{2}{|c|}{ Tidak } & \\
\hline & & $\mathrm{Jml}$ & $\%$ & $\mathrm{Jml}$ & $\%$ & $\mathrm{Jml}$ & $\%$ & \\
\hline 1. & $\begin{array}{l}\text { Apakah orang tua adikselalı } \\
\text { mengingatkan adik untuk melaksanakan } \\
\text { sholat lima waktu }\end{array}$ & 6 & 13 & 34 & 73 & 6 & 13 & 100 \\
\hline 2 & $\begin{array}{l}\text { Apakah kalian merasa bersalah jika } \\
\text { melakukanpelanggaranyang } \\
\text { bettentangand dengan norma+110ma } \\
\text { agama }\end{array}$ & 32 & 69 & 12 & 26 & 2 & 0,43 & 100 \\
\hline 3. & $\begin{array}{l}\text { Selain kegiatanbelajar mengajar, apakah } \\
\text { adikjuga aktif mengikutiki kegiatane exstra } \\
\text { kutikuler keagamazal }\end{array}$ & - & - & 24 & 22 & 22 & 47 & 100 \\
\hline
\end{tabular}


Tabel 3. menunjukkan bahwa : 1). Sebagai orang tua dirumah kurang memperhatikan anaknya dalam melaksanakan ibadah, hal tersebut menyebabkan anak tersebut kurang terbiasa untuk selalu melaksanakan shalat lima waktu, karena pada dasarnya keluargalah yang lebih berpengaruh terhadap pendidikan anaknya, 2). Tingkat kesadaran peserta didik sebenarnya masih tinggi, walaupun masih ada beberapa anak yang tingkat yang tingkat kesadarannya masih rendah, hal tersebut perlu ditindak lanjuti oleh guru dengan memberikan pembinaan dan pengalaman secara langsung, serta kegiatan-kegiatan yang produktif lainnya, sehingga kesadaran tersebut menemukan tempat dan tersalurkan sebagaimana mestinya, 3). Masih rendahnya kesadaran peserta didik untuk mengikuti kegiatan keagamaan yang diselenggarakan pihak sekolah.

Dengan demikian dapat diketahui bahwa, terjadinya pelanggaran yang dilakukan oleh peserta didik di sekolah, seperti merokok dilingkungan sekolah, membolos sekolah, tidak shalat berjama'ah di masjid sekolah, berkata kurang sopan atau kasar dan sebagainya disebabkan karena masih rendahnya tingkat kesadaran peserta didik terhadap prilaku yang kurang baik yang mereka lakukan dan juga disebabkan oleh faktor lingkungan dimana mereka tinggal. Penjelasan tersebut sesuai dengan yang dikemukakan oleh Abuddin Nata(2009) bahwa pembentukan akhlaq dipengaruhi oleh faktor internal yaitu pembawaan si anak dan faktor eksternal yaitu yaitu pendidikan dan pembinaan yang dibuat secara khusus atau melalui interaksi dalam lingkungan sosial, fitrah dan kecenderungan kearah yang baik yang ada dalam diri manusia dibina secara intensif melalui berbagai metode.

\section{KESIMPULAN}

Dari hasil pengolahan dan penganalisaan data pada bab sebelumnya, maka penulis dapat mengambil kesimpulan bahwa pembentukan akhlaq peserta didik di Madrasah Aliayah Hidaayatul Islaamiyah Sumber Agung Kemiling Bandar Lampung telah dilaksanakan dengan baik oleh guru Aqidaq Akhlaq sesuai dengan Undang- Undang Guru dan Dosen No.14 tahun 2005 bahwa tugas guru adalah, mendidik, mengajar, membimbing, mengarahkan, melatih menilai dan mengevaluasi peserta didik dalam proses pembelajaran di sekolah.

Akan tetapi meskipun guru aqidah akhlaq telah melaksanakan kinerjanya dengan baik, peserta didik masih melakukan pelanggaran - pelanggaran di sekolah tersebut. Hal ini disebabkan oleh faktor intern yakni rendahnya tingkat kesadaran peserta didik dalam mengaplikasikan setiap pembelajaran agama yang diajarkan disekolah dalam kehidupan sehari - hari dan faktor ekstern yakni pengaruh dari lingkungan baik dari keluarga maupun lingkungan masyarakat dimana peserta didik itu tinggal.

\section{DAFTAR PUSTAKA}

Agus Salim. 2004. Metode Penelitian Karya Ilmiah, Bandung: Gema Insani

Ali Muhammad. 2002. Penelitian Kependidikan Prosedur dan Strategi, Bandung: Angkasa

An Nahlawi. 2008. Pendidikan Islam Di Rumah, Sekolah dan Masyarakat, Jakarta: Gema Insani Pers

Ramayulis. 2004. Ilmu Pendidikan Islam.Jakarta : Kalam Mulia

Ahmad Tafsir, 2008. Metode Pengajaran Pendidikan Agama Islam, Jakarta: Remaja Rosda Karya

Jalaluddin. 2001.Teologi Pendidikan, Jakarta: Raja Gafrindo Persada

Sanjaya. 2005. Pembelajaran Dalam Implementasi Kurikulum Berbasis Kompetensi, Jakarta: Prenada Media

Sardiman. 2000. Interaksi dan Motivasi Belajar Mengajar, Jakarta: Raja Grafindo Persada

Lexi, J Manulang. 2004. Metode Penelitian Kualitatif, Bandung: Remaja Rosda Karya

Muhtarom, M., Purwanti, E. and Umurohmi, U., 2017. Implementasi Program Dakwah Sebagai Sarana Penanaman Nilai Pendidikan Agama Islam Untuk Peningkatan Akhlak Dan Peaktek Ibadah Siswa Di Smp 11 Maret Kec. Ambarawa Kab. Pringsewu. Jurnal Manajemen Pendidikan Islam Al-Idarah, 1(2), pp.45-52.

Zuhairini dkk. 2004. Metodik Khusus Pendidikan Agama, Jakarta: Usaha Nasional 